\title{
Unemployment and Its Determinants:A Study of Pakistan Economy (1999-2010)
}

\author{
Muhammad Arslan (Corresponding Author) \\ Bahria University Islamabad, Pakistan,PO box 440000, E-8, Islamabad, Pakistan \\ Email: MuhammadArslan73@Gmail.com \\ Rashid Zaman \\ Bahria University Islamabad, Pakistan,PO box 440000, E-8, Islamabad, Pakistan
}

\begin{abstract}
This study has been conducted to determine the determinants which cause the unemployment in economy of Pakistan for the period of 1999-2010. Unemployment is political and social issue in all the countries. In this foreign direct investment, gross domestic product rate, CPI based inflation rate and population growth rate is taken as explanatory variables. In this study ordinary least square model is used for determining the results. Findings of this paper shows that foreign direct investment, gross domestic product rate and CPI based inflation rate has negative impact on unemployment. Population growth rate has positive relationship with unemployment and it contributes to unemployment. This study also confirmed the tradeoff between inflation and unemployment. Keywords: Unemployment, Foreign Direct Investment, Gross Domestic Product, Inflation Rate
\end{abstract}

\section{Introduction}

Unemployment is one of the big and vital problems in all over the world. It is the common issue in developed as well as underdeveloped countries. It is the consistent problem facing by all industrially advance and as well as poor countries. Unemployment occurs when people are without jobs. Unemployment means people are able to work and actively finding job but fail to get a job.According to neoclassical economic, unemployment occurs when rigidities are imposed on labor market from the outside. But according to Keynesian economics, unemployment is due to in efficiency of markets and ineffective demand for goods and services.

According to IMF report (2008) 'unemployment is measured annually as percentage of that labor force which can't find job'. International labor Organization (2001) defines unemployment as a situation of being out of work or need a job and searching for it continuously in the last four week or remained unemployed at age 16 or above but available to join work in the next two weeks. People who reject low wage jobs or who don't want to work, like full time student, retired persons and children are not included in the unemployment.Involuntary unemployment is that which includes firing of workers due to an economic crisis, industrial decline, company bankruptcy or due to organizational restructuring.

Although, a lot of work has been done on the relationship between unemployment and other sets of macroeconomic variables but less attention is paid on the determinants of unemployment. In Pakistan, GDP fall in1990s and in 2000 it touched the lower point. Unemployment is the major issue in history of Pakistan. This paper determined the determinants of unemployment i.e. Population growth rate, inflation rate, Foreign Direct Investment and Gross Domestic Product growth rate in context of Pakistan economy. Population growth, inflation rate, foreign direct investment and gross domestic product taken as independent variables and unemployment were taken as dependent variable. In this the Linear Regression Model was used for analyzing of determinants of unemployment. In this paper the data is obtained from economic survey of Pakistan and IFS for the period of 1999-2010. Unemployment rate was quite high in 2000-20006. The second section deals with the literature review, theoretical framework and hypothesis. Third section deals with methodology and model specification. Section fourth presents empirical results of foreign direct investment, gross domestic product, inflation rate, population growth and unemployment. Conclusions and recommendations are in section 5 of paper.

\section{Literature Review}

Unemployment is becoming the most important and critical issue in Pakistan. Dramatic increase in growth of high level of unemployment is big headache for less-developed as well as developed countries. High level of unemployment can create number of social problems. There are various studies that investigated the determinants of unemployment. In these studies the determinants were investigated form micro as well as from macro perspectives in both less developed and developed countries. Different theoretical models are used in these studies. Buffie(1993) determined the impact of foreign direct investment on unemployment and capital accumulation in two sector dual economy model. His findings showed that foreign direct investment in high wage sector packed out domestic capital. Some of researchers presented a commonly chosen framework of job search model (Lippman \& McCall, 1976; Mortensen, 1970). According to this model when people became unemployed then their duration of unemployed depends upon the probability of accepting and receiving job 
offers. Unemployment gave rise to crime, suicides and also the poverty rates. Unemployment affects workers, their families and even the country because no job means:no income at individual level as well as national level. Some researchers used the information contained in nationally representative survey to analyze unemployment duration in Russia during early years of transitions (Foley, 1997). The findings of these researches indicate that married women were found to experience longer unemployment compared to their males. The findings also showed that older individual expected to be longer unemployed than that of younger individuals.Lipsey,et.al.(1997) argued that rivalry for markets was the one of the main reasons for a positive relationship between foreign direct investment and the domestic employment opportunities.

Elmeskov,et.al.(1998) focused on the relationship between unemployment and taxation in OCED countries for the period of 1983-1994. In this study the researcher used Hausman specification test and concluded that taxation has positive and exogenous impact on unemployment in short as well as long run. Findings showed that in long run, taxation as the major determinants of unemployment.Kingdon,et.al. (2001) studied the unemployment in South Africa by using theProbit model. In this study two national household surveys for the mid-1990s were used. The findings of this study indicated that unemployment in South Africa is determined by race, age, home, ownership and location.Izraeli and Murphy (2003) studied influence of degree of industrial diversification on unemployment rates and per capita income in seventeen states. The finding of this study showed that a state with more diversified base has lower unemployment rate. But the evidence on the relationship between per capita income and industrial diversification remained inconclusive. Kupets(2005) studied the determinants of unemployment in Ukraine between 1997-2003. In this study Ukrainian Longitudinal Monitoring Survey 2003 was used to investigate an individual conditional probability about leaving unemployed to employ. Chang (2006) studied the relationship between the economic growth, trade, unemployment and foreign direct investment in Taiwan. He applied VAR method of variance decomposition and also used impulse response function analysis. Findings showed that export and economic growth positively affected FDI inflow but export expansion was affected negatively onn FDI out flow. Study also determined that there were no relationship between FDI and unemployment. Negative relationship between economic growth and unemployment was confirmed and obvious.Bhorat(2007) studied number of social choice and labor economic theories and also identified variables that can determined the chance of somebody to be employed or not. Marika,et.al. (2007)studied the labor market to find the relationship between capital stock and unemployment. In this, researchers used indirect channels of transmission of capital stock for estimation of single equation unemployment model. Interest rates and investment ratios were used as major variables. They found that capital stock is key determinant of unemployment.Wright,et.al.(2009) analyzed the long term relationship between interest rates money supply and unemployment. They findings showed that these variables were positively related but at low frequencies. They also provided a unified theory for analysis of labor and goods markets.Akhtar,et.al.(2009) used comprehensive approach to unemployment by using VAR. Their main interest was in determining the interrelationship between Foreign Direct Investment, Export, Gross Domestic product and unemployment in Turkey. They used 2000-2007 period data. Their findings showed that foreign direct investment did not reduce unemployment in Turkey. Gross domestic product is positively affected by variations in exports but it is insignificant. They found no evidence that export led to growth in Turkey.Iqbal,et.al(2010)investigated the relationship between growth and unemployment for the period of 1972-2006. Researcher argued that GDP growth was the major source to minimize unemployment. They used ADF test. Their findings showed that for reducing unemployment there is need to accelerate growth. Sustained growth is key requirement for reducing unemployment.

\section{Theoretical Framework}

- Population Growth rate

- Foreign Direct Investment

- Gross Domestic Product growth rate

- Inflation rate

Independent Variables

Dependent Variable

Source: Adapt from (Khan, et.al. 2009) 


\section{Variables Description}

Population growth means the average annual percentage change in population, resulting from surplus or deficit of births over deaths and balance of migrants entering and leaving a country (United \& Population Division, 2010).

Foreign direct investments mean investments directly into production in a country. In this paper the data of FDI was in dollar million.Gross domestic product growth rate is on annual basis and it is adjusted for inflation and expressed as percent.Inflation rate is also in percentage on annual basis.Unemployment rate is percent of labor force that is without jobs.

\section{Hypothesis}

H1: Population growth is negatively related with unemployment.

H2: Foreign direct investment is negatively related with unemployment.

H3: Gross domestic product is negatively related with unemployment.

H4: Inflation and unemployment are negatively related with each other.

\section{Research Methodology}

It is well established from literature that unemployment has significant impact on foreign direct investment, population growth, gross domestic product and inflation rate.In this study we examined whether variation in unemployment is associated with foreign direct investment, population growth, gross domestic product and inflation rate.

\subsection{Secondary Data}

Secondary data refer to information thatis collected by individuals, agencies and institutions other than by the researcher Welman et.al.(2005). Secondary data is data which is collected for previous projects other than current project. In this paper the sample were consisted of 12 years of data from 1999-2010. Data on each issue was taken from different economic survey of Pakistan. Some data is taken from IFS. E-view 6 was used for empirical work.Unemployment rate, inflation rate, population growth rate, foreign direct investment and gross domestic productgrowth rate were taken as variables.

3.2 Model Specification

The simple linear regression model was used in the study is given below:

$\mathrm{Y}=\beta^{\mathrm{o}}+\beta \mathrm{F}+\mho$

In above equation $\mathrm{Y}$ is the presenting the unemployment rate and it is dependent variable. It is constant. $\beta$ is the coefficient of independent variables. $\mho$, is the error term and it is assumed to have zero mean and independent across time period.

By adopting the above model, the equation for this paper evolves:

Unemployment Rate $=\beta^{\circ}+\beta_{1} \mathrm{PG}+\beta_{2} \mathrm{FDI}+\beta_{3} \mathrm{INR}+\beta_{4} \mathrm{GDP}+\mho$

In this equation the PG means population growth, FDI means foreign direct investment, INR means inflation rate and GDP means the gross domestic product. There were few studies by taking population growth, foreign direct investment and inflation rate (Chang, 2006; khan,et.al. 2009; Ozturk \& Akhtar, 2009). GDP growth rate was included in addition and data was from 2000-2010 for authenticating results. FDI was in millions of dollars and rest of variables was measured in growth or percentage change.

\section{Empirical Results}

The table 1 showed that FDI has inversely relationship with unemployment. And this relationship is significant. As the FDI inflows increases in a country then unemployment reduces because FDI provides new opportunities and thus helping in reducing the unemployment. The t-test is used for supporting null hypothesis and it shows that null hypothesis should reject because value of t-test is greater than 2 . These results are consistent with previous studies Khan,et.al(2010; Walterskirchen, 2008). GDP has negative relationship with unemployment and this relationship is significant because the probability is less than $5 \%$. The $\mathrm{t}$ - stats show that null hypotheses should reject because the value of $t$ is greater than 2. According to Okun's Law higher the GDP lower the unemployment. These findings are supported by previous literature (M.Rafiq, et al., 2010; Rizvi \& Nishat, 2009; Iqbal,et.al.2010; Walterskirchen, 2008).

Table shows that inflation and unemployment are inversely related with each other. $\mathrm{T}$ stats show that we should reject the null hypothesis. It means if inflation increases the unemployment decreases. There is significant negative relationship between inflation and unemployment(M.Rafiq, et al., 2010). These findings are supported by Phillip (1958). According to Phillips curve (1958) there is inverse relationship between inflation and unemployment. There are tradeoff between inflation and unemployment in short run. But in long run this tradeoff has not been observed. Empirical findings showed that population growth has significant positive relationship with unemployment. If population growth rate increases then the unemployment also increases. In previous studies many researches showed that high level of population growth erode the economy. And has negative impact on macroeconomic variables (Kalim, 2003; M.Rafiq, et al., 2010). Findings of this study show 
that Pakistani population is growing annually by $1.8 \%$, which is very high. This high rate of population is key determinants of unemployment.

The value of R-square is 0.86 which indicate very well fit to data. It means that $86 \%$ change in dependent variable is due to these explanatory variables i.e. foreign direct investment, gross domestic product, population growth and Inflation rate. Rest of change is due to other variables which are unexplained. The value of Durbin Watson stats shows that there is perhaps minimum auto correlation between the variables because value is near 2 . The probability in $\mathrm{f}$ stats shows that the model is significant and related to our study.

\section{Conclusions and Recommendations}

Unemployment is one of the common issues in all over the world. It is becoming a major problem for less developed and also for developed countries. It is very consistent problem and for many countries it remains difficult to manage. Unemployment can be analyzed by different dimensions. But this paper focuses on the determinants of unemployment. Results of this paper showed that $\mathrm{H} 1$ is rejected and $\mathrm{H} 2, \mathrm{H} 3$ and $\mathrm{H} 4$ are accepted.Paper showed that foreign direct investment, inflation rate, and gross domestic product have negative relationship with unemployment. Population growth has positive relationship with unemployment and it contributes to unemployment. According to findings of this paper population growth is the key determinants of unemployment. In this paper the tradeoff between the inflation and unemployment in Pakistan economy is also observed. But there is need to do more research to check whether this tradeoff is short run or long run.

It is recommended that government should focus on foreign direct investments. Government should adopt policies for attracting foreign investors to come and invest. Government should also control the inflation rates for controlling the unemployment. Policy makers should know that which rate of Gross domestic product can benefited in bringing down unemployment. Government should apply policies to control population growth rate.

\section{Future Research}

More variables can be added i.e. exports, labor market policies, capital stock etc. The data can be increased for getting more authenticated research. This research can be done in other countries.

\section{References}

Aleksander, B., Guido Menzio, \& Wright, R. (2009). Inflation and Unemployment in the Long Run.

Bhorat, H. (2007). Unemployment in South Africa: Descriptors and Determinants. Washington DC.: World Bank.

Blomström, M., Fors, G., \& Lipsey, R. E. (1997). Foreign Direct Investment and Employment: Home Country Experience in the United States and Sweden. The Economic Journal, 107 1787-1797.

Buffie. (1993). Direct Foreign Investment, Crowding Out, and Underemployment in the

Dualistic Economy. Oxford Economic Papers, 45(4), 639-667.

Chang, S.-C. (2006). The dynamic interactions among foreign direct investment, economic growth, exports and unemployment: evidence from Taiwan. Economic Change(38), 235-256.

Elmeskov, J., Martin, J. P., \& Scarpetta, S. (1998). Unemployment and Labor Market Rigidities in OECD Countries - The Impact of Taxes. Swedish Economic Policy Review, 5(2), 207-258.

Foley, M. C. (1997). Determinants of Unemployment in Russia

University. Center Discussion Paper. Yale.

Kalim, R. (2003). Population and Unemployment: A Dilemma to Resolve. The IUP Journal of Applied Economics, 2(3), 7-15.

Kingdon, G., \& Knight, J. (2001). Race and the Incidence of Unemployment in South Africa. Centre for the Study of African Economies Working Papers.

Kupets, O. V. (2005). Determinants of unemployment duration in Ukraine-Moscow. : EERC." Economics Education and Research Consortium.

Lippman, S., \& McCall, J. (1976). The Economics of Job Search: A Survey (Vol. 14, pp. 155-189): Economic Inquiry.

M.Rafiq, Ahmad, I., ullah, A., \& Khan, Z. (2009). DETERMINANTS OF UNEMPLOYMENT: A CASE STUDY OF PAKISTAN ECONOMY (1998-2008)

Abasyn Journal of Social Sciences, 3(1).

M.Rafiq, Ahmad, I., ullah, A., \& Khan, Z. (2010). DETERMINANTS OF UNEMPLOYMENT: A CASE STUDY OF PAKISTAN ECONOMY (1998-2008)

Abasyn Journal of Social Sciences, 3(1).

Marika Karanassou, Hector Sala, \& Salvador, P. F. (2007). Capital Accumulation and Unemployment: Capital Accumulation and Unemployment: new insights on the Nordic, experience. Economics review, 90(2), 1223-1322.

Mortensen, D. (1970). Job Search, the Duration of Unemployment and the Phillips Curve. American Economic Review, 30(847-862). 
Ozturk, L., \& Akhtar, I. (2009). Can Unemployment be Cured by Economic Growth and Foreign Direct Investment in TURKEY? International Research Journal of Finance and Economics, 27, 1450-2887.

Rizvi, S. Z. A., \& Nishat, D. M. (2009). The Impact of Foreign Direct Investment on Employment Opportunities: Panel Data Analysis,Empirical Evidence from Pakistan, India and China.

T. Hussain, Siddiqi, M. W., \& Iqbal, A. (2010). A Coherent Relationship between Economic Growth and Unemployment: An Empirical Evidence from Pakistan. International Journal of Human and Social Sciences, 5(5).

United, N., \& Population Division. (2010). World Population Prospects

Walterskirchen, E. (2008). THE RELATIONSHIP BETWEEN GROWTH, EMPLOYMENT AND UNEMPLOYMENT IN THE EU. Vienna: Austrian Institute of Economic Research.

Welman, C., Kruger, F., \& Mitchel, B. (2005). Research Methodology Oxford University Press (Vol. 3). Cape Town.

Table 1.

\begin{tabular}{|c|c|c|c|c|}
\hline \multirow{2}{*}{$\begin{array}{l}\text { Dependent Variable: UNEMPLOYMENT RATE } \\
\text { Method: Least Squares } \\
\end{array}$} & \multirow[b]{4}{*}{ Coefficient } & \multirow[b]{4}{*}{ Std. Error } & \multirow[b]{4}{*}{ t-Statistic } & \multirow[b]{4}{*}{ Prob. } \\
\hline & & & & \\
\hline Included observations: 12 & & & & \\
\hline Variable & & & & \\
\hline $\mathrm{C}$ & 10.95386 & 1.866403 & 5.868966 & 0.0006 \\
\hline FOREIGN DIRECT INVESTMENT & -0.000316 & 0.00013 & -2.440649 & 0.0447 \\
\hline GROSS DOMESTIC PRODUCT & -0.200344 & 0.069745 & -2.872521 & 0.0239 \\
\hline INFALTION RATE & -0.098316 & 0.047112 & -2.086869 & 0.0753 \\
\hline POPULATION GROWTH RATE & 2.054178 & 0.831804 & 1.949545 & 0.0429 \\
\hline R-squared & 0.864058 & \multicolumn{2}{|c|}{ Mean dependent var } & 6.424167 \\
\hline Adjusted R-squared & 0.786376 & \multicolumn{2}{|c|}{ S.D. dependent var } & 1.04155 \\
\hline S.E. of regression & 0.481399 & \multicolumn{2}{|c|}{ Akaike info criterion } & 1.670095 \\
\hline Sum squared resid & 1.622212 & \multicolumn{2}{|c|}{ Schwarz criterion } & 1.872139 \\
\hline Log likelihood & -5.020567 & F-statistic & & 11.12311 \\
\hline Durbin-Watson stat & 2.165605 & \multicolumn{2}{|c|}{ Prob(F-statistic) } & 0.003728 \\
\hline
\end{tabular}


The IISTE is a pioneer in the Open-Access hosting service and academic event management. The aim of the firm is Accelerating Global Knowledge Sharing.

More information about the firm can be found on the homepage:

http://www.iiste.org

\section{CALL FOR JOURNAL PAPERS}

There are more than 30 peer-reviewed academic journals hosted under the hosting platform.

Prospective authors of journals can find the submission instruction on the following page: http://www.iiste.org/journals/ All the journals articles are available online to the readers all over the world without financial, legal, or technical barriers other than those inseparable from gaining access to the internet itself. Paper version of the journals is also available upon request of readers and authors.

\section{MORE RESOURCES}

Book publication information: http://www.iiste.org/book/

\section{IISTE Knowledge Sharing Partners}

EBSCO, Index Copernicus, Ulrich's Periodicals Directory, JournalTOCS, PKP Open Archives Harvester, Bielefeld Academic Search Engine, Elektronische Zeitschriftenbibliothek EZB, Open J-Gate, OCLC WorldCat, Universe Digtial Library, NewJour, Google Scholar

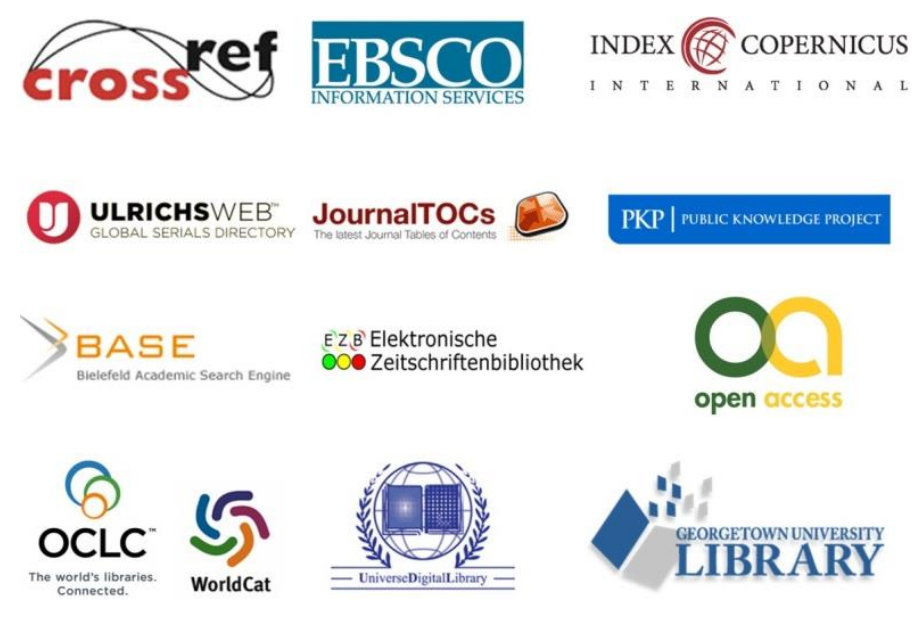

